\title{
PENGARUH PERUSAHAAN STARTUP TERHADAP PERTUMBUHAN EKONOMI INDONESIA SELAMA PANDEMI COVID-19
}

\author{
${ }^{1}$ Dhiyaah Karina*, ${ }^{2}$ Siti Alfiyatus Sa'diyah, ${ }^{3}$ Hanna Nabilah, ${ }^{4}$ Maya Panorama \\ 1,2,3,4 UIN Raden Fatah Palembang \\ Email: ${ }^{1} 1920602043 @$ radenfatah.ac.id, $21930602257 @$ radenfatah.ac.id, \\ 31920602106@radenfatah.ac.id, ${ }^{4}$ maya.izuddin@gmail.com
}

\begin{abstract}
ABSTRAK
Pandemi Covid-19 memberikan dampak yang sangat besar terhadap perekonomian Indonesia sehingga terjadinya krisis ekonomi. Perusahaan Startup adalah sebuah usaha yang baru berjalan dan menerapkan inovasi teknologi untuk menjalankan core businessnya dan dapat memecahkan sebuah masalah di masyarakat. Fokus penelitian ini adalah untuk membuktikan berpengaruh atau tidaknya perusahaan startup terhadap pertumbuhan ekonomi Indonesia. Penelitian ini menggunakan pendekatan kualitatif. Penlitian ini menggunakan metode Pendekatan kualitatif dengan jenis Case studies yang merupakan penelitian kualitatif dimana peneliti melakukan eksplorasi secara mendalam terhadap perusahaan startup dan keadaan perekonomian di Indonesia selama pandemi Covid-19. Suatu kasus terikat oleh waktu dan aktivitas dan peneliti melakukan pengumpulan data secara mendetail dengan menggunakan berbagai prosedur pengumpulan data dan dalam waktu yang berkesinambungan. Dari hasil penelitian, penulis menyimpulkan bahwa perusahaan startup sangat berpengaruh terhadap pertumbuhan ekonomi Indonesia selama pandemi covid-19. Perusahaan startup yang menjadi bagian ekonomi digital berkontribusi sebesar 4\% dari GDP. Perusahaan Startup dapat bertahan dan mendorong ekonomi Indonesia disaat banyak sektor ekonomi lain yang gugur. Terutama perusahaan startup sektor e-commerce yang meningkat pesat.
\end{abstract}

Kata kunci: Pertumbuhan Ekonomi, Perusahaan Startup, Ekonomi Digital

\begin{abstract}
The Covid-19 pandemic has had a huge impact on the Indonesian economy, resulting in an economic crisis. A startup company is a business that is just running and applies technological innovation to run its core business and can solve a problem in society. The focus of this research is to prove whether or not startup companies have an impact on Indonesia's economic growth. This study uses a qualitative approach. This research uses a qualitative approach method with the type of case studies which is a qualitative research in which researchers conduct in-depth explorations of startup companies and the state of the economy in Indonesia during the Covid-19 pandemic. A case is bound by time and activity and the researcher collects detailed data using various data collection procedures and in a continuous time. From the results of the study, the authors conclude that startup companies are very influential on Indonesia's economic growth during the covid-19 pandemic. Startup companies that are part of the digital economy contribute 4\% of GDP. Startup companies can survive and drive the Indonesian economy when many other economic sectors are falling. Especially startup companies in the e-commerce sector which are growing rapidly.
\end{abstract}

Keywords: Economic Growth, Startup Companies, Digital Economy

\section{PENDAHULUAN}

Pembangunan ekonomi dan pertumbuhan ekonomi adalah dua hal yang saling berkaitan. Petumbuhan ekonomi mempengaruhi keberhasilan pambangunan ekonomi suatu negara. Proses dalam mencapai kenaikkan pendapatan total dan pendapatan perkapita yang emperhitungkan adanya pertambahan penduduk dan disertai oleh suatu perubahan fundamental dalam struktur ekonomi suatu negara dan pemerataan pendapatan bagi penduduk suatu negara disebut sebagai pembangunan ekonomi. Jika suatu Negara terjadi peningkatan produk nasional bruto (GNP) riil maka telah terjadi pertumbuhan ekonomi. 
Pada maret tahun 2020, Indonesia dihebohkan dengan adanya virus corona atau severe acute respiratory syndrome coronavirus 2 (SARS-CoV-2) yang masuk ke Indonesia. Virus Corona tersebut ditemukan pertama kali di kota Wuhan, China pada akhir Desember 2019. Nama popular dari virus tersbut adalah Covid-19 (Corona Virus Disease 2019. Virus tersebut tidak hanya menyebar ke Indonesia tetapi hampir di semua Negara di Dunia. Covid-19 ini menginfeksi sistem pernapasan yang menyebabkan timbulnya flu, pneumonia, hingga kematian. ${ }^{1}$

Dampak dari adanya virus Covid-19 ini sangat besar terutama pada perkonomian Indonesia. Virus tersebut menjadi penyebab utama terjadinya krisis ekonomi. Dalam mengurangi penyebaran virus tersebut Pemerintah Indonesia telah memberlakukan berbagai jenis kebijakkan. Salah satu kebijakkan tersebut adalah pembatasan aktivitas masyarakat, seperti lockdown, physical distancing, Pembatasan sosial berskala besar (PSBB), dan Perberlakukan Pembatasan Kegiatan Masyarakat (PPKM). Kebijakkan-kebijakkan tersebut memberikan pengaruh pada tingkat pertumbuhan ekonomi di Indonesia sehingga ekonomi di Indonesia mengalami defisit. Pembatasan dalam ruang gerak masyarakat Indonesia mengakibatkan aktivitas perekonomian menurun, terbatasnya mobilitas barang dan jasa, permintaan dan penawaran atas barang dan jasa menurun, dan lain-lain sehingga pendapatan di berbagai sector ekonomi di Indonesia menurun.

\footnotetext{
${ }^{1}$ Fakhrul Rozi Yamali dan Ririn Noviyanti Putri, "Dampak Covid-19 Terhadap Ekonomi Indonesia", Journal Of Economics And Business, 4 (2), 384-388, 2020.

${ }^{2}$ Muhammad Dzul Fadlli, "Pertumbuhan Ekonomi 2020 Minus, lebih rendah dari perkiraan
}

Angka pertumbuhan ekonomi Indonesia yang dirilis oleh Badan Pusat

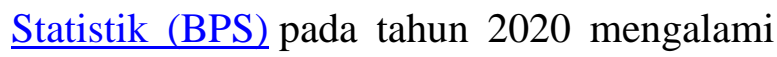
kontraksi pertumbuhan sebesar 2,07\% (c-to-c) jika dibandingkan dengan tahun 2019. Terdapat 10 sektor ekonomi Indonesia mengalami pertumbuhan ekonomi sektoral negatif. Yang terdiri dari sektor transportasi dan pergudangan yang mengalami penurunan yang sangat parah dengan pertumbuhan $15,04 \%$. Selanjutnya ada sektor akomodasi dan makan minum yang mengalami kontraksi hingga $-10,22 \%$. Kemudian sektor-sektor lain yang juga mengalami hal tersebut adalah sector pengolahan, konstruksi, perdagangan, administrasi pemerintahan, pertambangan dan penggalian, pengadaan listrik \& gas, jasa lainnya, dan jasa perusahaan. Tetapi masih ada banyak sektor ekonomi lain yang tidak mengalami pertumbuhan sektoral negatif, yaitu sektor jasa kesehatan \& kegiatan sosial dan informasi dan komunikasi yang mampu mencatatkan pertumbuhan ekonomi yang semakin tinggi dari tahun sebelumnya. Selain sector tersebut terdapat sektor pertanian, kehutanan, dan perikanan, Jasa Keuangan dan Asuransi, Jasa Pendidikan, Real Estat, dan Pengadaan Air yang juga tumbuh positif meskipun terjadi perlambatan. Tetapi secara umum pertumbuhan ekonomi Indonesia 2020 mengalami tekanan. ${ }^{2}$

Perusahaan startup pintar dalam mencari peluang yang seiring dengan perubahan gaya hidup masyarakat sehingga bisa bersaing lebih baik terutama pada saat pandemic covid-19 saat ini. Perusahaan

pemerintah", diakses dari laman https://studiekonomi.com/nasional/pertumbuha n-ekonomi-2020-minus-lebih-rendah-dariperkiraan-pemerintah/ pada 14 Desember 2021 pukul 17.30 
startup adalah perusahaan yang berinovasi dalam teknologi digital berdasarkan perkembangan zaman sebagai keunggulannya. Perusahaan startup menghasilkan profit dengan memberikan solusi atas permasalahan yang ada di masyarakat. Beberapa produk inovasi tekonologi digital perusahaan startup yang populer digunakan oleh masyarakat ada Gojek, Grab, Tokopedia, Lazada, Shopee, Quipper, Ruangguru, HaloDoc, Dokter.id, OVO, LinkAja, Dana, Tanihub, Sayurbox, dan lain-lain yang merupakan perusahaan penyedia layanan barang dan jasa dengan teknologi digital. Karena adanya pembatasan dalam banyak hal saat pandemic covid-19 maka banyak masyarakat menggunakan teknologi digital untuk memenuhi kebutuhannya. Perusahaan startup juga mempermudah penjual dan pelayanan jasa dalam menjual barang dan jasa mereka sehingga produsen dan konsumen di Indonesia dapat bertahan menghadapi covid19.

Sandiaga Salahuddin Uno $^{3}$ sangat yakin bahwa startup digital Indonesia dapat memainkan peran penting dalam pertumbuhan ekonomi di Indonesia. Indonesia adalah salah satu Negara dengan ekonomi digital terbesar di Asia Tenggara. Nilai pasar Indonesia pada 2019 sebesar USD 140 miliar yang akan menjadi USD124 miliar pada tahun 2025 sehingg meningkat tiga kali lipat jika kedua tahun tersebut dibandingkan. Pengurus Inti Coworking ID \& Ketua

\footnotetext{
${ }^{3}$ Menteri Pariwisata dan Ekonomi Kreatif Republik Indonesia

${ }^{4}$ Program Baparekraf for Startup (BEKUP) yang dibuka oleh Kementerian Pariwisata dan Ekonomi Kreatif pada tahun 2021 sebagai upaya membangkitkan sektor pariwisata dan ekonomi kreatif di tengah pandemi covid-19.
}

Pelaksana BEKUP 2021 menyatakan bahwa pihaknya telah melihat sendiri bagaimana para pelaku startup tanah air terus berusaha untuk berkembang meski di tengah krisis pandemi. $^{5}$

Berdasarkan hal tersebut, penelitian ini penting dilakukan untuk menganalisis pengaruh perusahaan startup terhadap pertumbuhan ekonomi di Indonesia selama pandemic covid-19.

\section{KERANGKA TEORI \\ Pertumbuhan Ekonomi}

Peningkatan jangka panjang dalam meningkatkan kapasitas penyediaan barangbarang ekonomi untuk penduduknya oleh suatu negara disebut sebagai pertumbuhan ekonomi. Kenaikan kapasitas dapat terjadi jika ditunjang dengan menyesuaikan dengan kemajuan dalam hal teknologi, kelembagaan, dan ideologis terhadap berbagai tuntutan keadaan yang ada (Kuznets, 1971). Produk Domestik Bruto (PDB) atau Gross Domestic Product (GDP) merupakan variabel yang harus diperhatikan dalam mengukur pertumbuhan ekonomi. Produk Domestik Bruto (PDB) merupakan total jumlah produksi suatu barang dan jasa yang dihasilkan oleh suatu negara atau wilayah dalam waktu tertentu.

\section{Pertumbuhan Ekonomi Indonesia Pada Masa Pandemi Covid-19}

Pertumbuhan ekonomi negara Indonesia mengalami penurunan yang disebabkan oleh wabah virus corona.

\footnotetext{
${ }^{5}$ Husen Miftahudin. Dorong Pemulihan Ekonomi, Menparekraf Genjot Peran Startup Digital RI diakses dari https://www.medcom.id/ekonomi/bisnis/4KZzWqJ K-dorong-pemulihan-ekonomi-menparekrafgenjot-peran-startup-digital-ri pada tanggal 2 November 2021
} 
Kebijakan yang diberlakukan pemerintah untuk mencegah penyebaran virus corona seperti lockdown, Kebijakan Pembatasan Sosial Berskala Besar (PSBB) dan PPKM (Pemberlakuan Pembatasan Kegiatan Masyarakat) menjadi penyebab terbesar ekonomi Indonesia mengalami penurunan. Kebijakkan tersebut membuat sejumlah kegiatan perekonomian tidak dapat berjalan dengan normal dan lancar.

Ada banyak kerugian yang disebabkan oleh Covid-19 untukperekonomian Indonesia. Beberapa kerugian yang disebabkan oleh adanya Virus Corona ini antara lain, angka impor Indonesia menurun sebesar 3,7\% dalam rentang waktu Januari sampai Maret 2020. Selanjutnya terdapat 12.703 lebih penerbangan di 15 bandara dibatalkan dalam rentang waktu Januari sampai Februari. Penerbangan tersebut terdiri dari 11.680 penerbangan domestik dan 1.023 penerbangan internasional. Pertumbuhan ekonomi Indonesia diperkirakan turun sebesar $2.3 \%$ bahkan dapat menembus angka $-0,4 \%$ sebagai akibat dari adanya Virus Corona ini. ${ }^{6}$

$$
\text { Badan Pusat Statistik (BPS) }
$$
menyatakan bahwa ekonomi Indonesia tumbuh melambat sebesar 2,97\% pada kuartal I per tahun 2020. Jika dibandingkan dengan kuartal IV per tahun 2019 pertumbuhan ekonomi Indonesia mengalami penurunan sebesar $2,41 \%$. Daya beli masyarakat yang melemah menjadi salah satu faktor pertumbuhan ekonomi Indonesia melambat. Pengeluaran pertumbuhan ekonomi menjadikan daya beli. Pertumbuhan konsumsi rumah tangga mencapai $2,84 \%$, saat kondisi

\footnotetext{
6 Ibid.

7 Ibid.

${ }^{8}$ Mardi Arya Jaya , Ridi Ferdiana, dan Silmi Fauziati, “Analisis Faktor Keberhasilan Startup Digital di Yogyakarta Mardi” 167-173, 2017.
}

pandemi ini. Hal itu melambat jika dibandingkan dengan kuartal IV per tahun 2019 yang dapat mencapai angka 5,02\%. Konsumsi rumah tangga dapat menopang lebih dari 50\% produk domestik bruto. ${ }^{7}$ Maka dari itu pertumbuhan konsumsi rumah tangga penting dalam meningkatkan pertumbuhan ekonomi Indonesia.

\section{Perusahaan Startup}

Startup adalah sebuah perusahaan yang belum lama berdiri atau beroperasi. Startup adalah sebuah perusahaan yang menciptakan produk atau jasa ditengah ketidakpastian dan dapat menemukan sebuah model bisnis yang dapat berulang dan berskala. ${ }^{8}$ istilah perusahaan startup biasanya mengacu pada perusahaan-perusahaan yang layanan atau produknya berbasiskan teknologi.

$$
\text { Perusahaan-perusahaan startup }
$$
sebagian besar merupakan perusahaan yang baru didirikan dan masih dalam fase penelitian dan pengembangan untuk memperoleh pasar yang cocok. Perkembangan startup di Indonesia bisa dikatakan cukup cepat, setiap tahun ataupun setiap bulan banyak pemilik startup baru bermunculan. Beberapa contoh startup yang sudah berkembang di Indonesia yaitu, Bukalapak.com, Go-jek, Traveloka, Kitabisa.com, Grab, Tiket.com, Uber, dan lain sebagainya. ${ }^{9}$

Indonesia menduduki posisi lima dunia dengan 2.193 startup pada 2019 setelah AS, India, Inggris, dan Kanada dengan kualitas startup yang unggul. Kualitas startup

\footnotetext{
${ }^{9}$ I. Husnayain and M. K. Mawardi, "Implementasi lean canvas pada startup dalam menghadapi persaingan," J. Adm. Bisnis, vol. 55, no. 2, pp. 3038, 2018.
} 


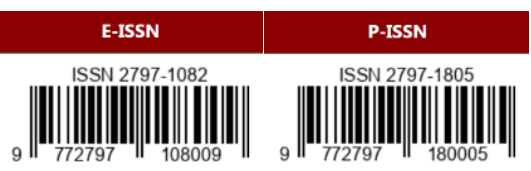

Volume 2 Nomor 1 (Desember 2021 - Februari 2022)

di Indonesia pun kian tangguh dengan adanya empat unicorn yaitu starup dengan valuasi lebih dari 1 juta dollar AS dan satu decacorn yaitu valuasi lebih dari 10 juta dollar AS. Valuasi pasar unicorn dan decacorn itu juga mendominasi dunia startup Asia Tenggara. Beberapa di antaranya Traveloka dengan valuasi 4,5 miliar dollar AS, Gojek dengan valuasi sebesar 11 miliar dollar AS, Tokopedia dengan valuasi sebesar 7 miliar dollar AS, OVO dengan valuasi sebesar 2,9 miliar dollar AS, dan Bukalapak dengan valuasi sebesar 12 miliar dollar AS. ${ }^{10}$

\section{METODE PENELITIAN}

Penelitian ini menggunakan pendekatan kualitatif. Pendekatan kualitatif merupakan sebuah proses untuk memahami masalah sosial. Jenis pendekatan kualitatif yang peneliti gunakan adalah Case studies yang merupakan tekhnik peneliti dalam melakukan eksplorasi penelitian kualitatif secara mendalam terhadap perusahaan startup dan keadaan perekonomian di Indonesia selama pandemi Covid-19. Terdapat kasus yang terikat oleh waktu dan aktivitas sehingga peneliti dapat melakukan pengumpulan data secara mendetail dengan menggunakan berbagai macam prosedur pengumpulan data dalam waktu yang berkesinambungan.

\section{HASIL DAN PEMBAHASAN}

Pada sekitar tahun 2000-an sejak masa industri 'dot-com' populer, makna 'startup' di

\footnotetext{
${ }^{10}$ Kompas.com. "Di WEF 2020, Menkominfo Pamerkan Pesatnya Perkembangan Startup Indonesia" diakses pada tanggal 3 November 2021 di laman https://kominfo.go.id/content/detail/23975/di-wef2020-menkominfo-pamerkan-pesatnyaperkembangan-startup-indonesia/0/sorotan media

${ }^{11}$ CoHive, "Apa Yang Dimaksud Dengan Digital Startup?", diakses dari laman
}

dunia bisnis pun mengalami pergeseran arti. Definisi dari Startup saat ini adalah sebuah usaha yang baru berjalan dan menerapkan inovasi teknologi untuk menjalankan core business-nya dan dapat memecahkan sebuah masalah di masyarakat. ${ }^{11}$

Sebagai pemecah masalah, startup memiliki karakter pertumbuhan pendapatan yang cepat sekitar 10 persen per minggu, memiliki pasar yang besar dancapital efficient. Karakter ini membantu perekonomian dan dicapai melalui penggunaan teknologi. ${ }^{12}$ Kualitas startup di Indonesia pun kian tangguh dengan munculnya empat unicorn (valuasi lebih dari 1 juta dollar AS) dan satu decacorn (valuasi lebih dari 10 juta dollar AS). Valuasi pasar unicorn dan decacorn itu juga mendominasi dunia startup Asia Tenggara. Beberapa di antaranya Gojek (11 miliar dollar AS), Tokopedia (7 miliar dollar AS), Traveloka (4,5 miliar dollar AS), OVO (2,9 miliar dollar AS), dan Bukalapak (12 miliar dollar AS). ${ }^{13}$

Hasil riset Google, Temasek, dan Bain \& Company mencatat ekonomi digital terbesar di Asia Tenggara adalah Indonesia. Potensinya tersebut pun semakin tinggi seiring dengan adaptasi kebiasaan baru dari offline ke online. Nilai ekonomi digital Indonesia yang tercermin dari total nilai penjualan atau gross merchandise value (GMV) sebesar US\$ 70 miliar pada 2021. Proyeksi GMV ini kembali meningkat menjadi US\$ 146 miliar pada 2025. Kenaikan

\footnotetext{
https://cohive.space/blogs/apa-itu-digital-startup/ pada 14 Desember 2021

12 Pratiwi Agustini, “Tiga Karakter Startup Digital Bantu Pertahankan Ekonomi Indonesia”, diakses dari laman https://aptika.kominfo.go.id/2021/07/tigakarakter-startup-digital-bantu-pertahankanekonomi-indonesia/ Pada 5 Desember 2021

${ }^{13}$ Kompas.com, Loc. cit.
} 


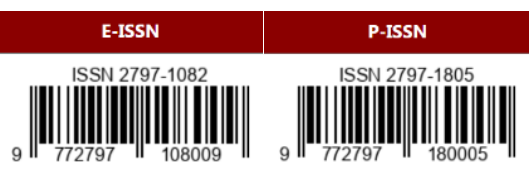

Volume 2 Nomor 1 (Desember 2021 - Februari 2022)

proyeksi tersebut didukung oleh tingkat penjualan e-commerce yang US\$ 53 miliar pada 2021, dan diperkirakan meningkat menjadi US\$ 104 miliar pada 2025. ${ }^{14}$

Teknologi yang berkembang pesat memberikan kemudahan untuk belanja suatu barang di wilayah Indonesia maupun barang yang berasal dari luar negeri tanpa harus mengunjunginya. Media-media yang ramai digunakan saat ini diantaranya adalah website, e-commerce, dan social media. Perubahan ini juga terjadi pada sistem pembayaran tunai yang dahulu hanya bisa menggunakan kartu debit ataupun kredit saat ini berlaih ke pembayaran secara digital dengan berbagai aplikasi yang dikeluarkan oleh bank terkemuka ataupun perusahaan penyedia jasa lainnya. Teknologi komunikasi memberikan kesempatan bagi penjual untuk menjangkau konsumen secara lebih luas dan mudah. ${ }^{15}$

Pembayaran dompet digital telah populer dan paling diterima sebagai metode pembayaran yang muncul di negara maju dan berkembang. Dompet digital terus tumbuh dan mempengaruhi banyak faktor seperti peningkatan penyebaran, penetrasi seluler, inklusi keuangan, lebih nyaman, lebih cepat, dan lebih ekonomis. Pembayaran secara digital seperti ini mempunyai fungsi yang penting dalam pembentukan ekosistem mulai dari pengaturan, institusi keuangan, manufaktur alat, pengecer atau penjual, hingga konsumennya sendiri. Seperti di masa pandemi Covid-19, dompet digital semakin

\footnotetext{
${ }^{14}$ Dwi Hadya Jayani, "Sektor Potensial Ekonomi

Digital Indonesia", diakses dari laman https://katadata.co.id/ariayudhistira/infografik/61ae fade065a4/sektor-potensial-ekonomi-digitalindonesia pada 14 Desember 2021 pukul 20.00 WIB

${ }^{15}$ Sisca Aulia. "Pola Perilaku Konsumen Digital

Dalam Memanfaatkan Aplikasi Dompet

Digital." Jurnal Komunikasi 12.2 (2020), p. 312.
}

digunakan sebagai alat pembayaran karena tidak perlu bersentuhan dengan uang (cashless). Hal ini sesuai dengan anjuran kebijakan jaga jarak atau physical distancing dari World Health Organization (WHO) yang membuat banyak konsumen terinspirasi untuk melakukan aktivitas dengan kontak seminim mungkin, termasuk melakukan transaksi pembayaran. ${ }^{16}$

Laporan State of Finance App Marketing AppsFlyer 2021 meneliti 2,7 miliar instalasi aplikasi di Asia Pasifik dari total 4,7 miliar aplikasi Fintech dunia di kuartal I-2019 dan kuartal I-2021. ${ }^{17}$

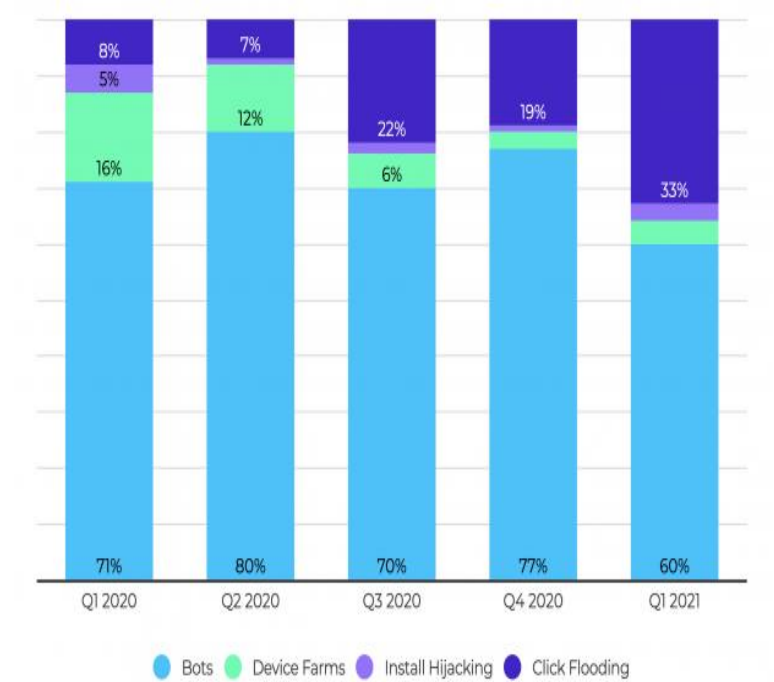

Sumber: Katadata.co.id

Di tahun 2020 menunjukkan peningkatan $17 \%$ atau kira - kira mencapai 25 juta pengguna internet dari 272 juta penduduk Indonesia, terdapat sekitar $64 \%$ penduduk Indonesia yang dapat mengakses ke dunia maya. Pengguna jaringan internet dalam kisaran umur 16 sampai 64 tahun,

\footnotetext{
${ }^{16}$ Ibid.

${ }^{17}$ Intan Nirmala Sari, "Indonesia Pengguna Fintech Tertinggi Ketiga di Dunia" diakses dari laman https://katadata.co.id/intannirmala/digital/60d1c95 ea19bb/indonesia-pengguna-fintech-tertinggiketiga-di-dunia pada 5 Desember 2021.
} 
menggunakan perangkat, antara lain mobile phone mencapai 96\%, smartphone berjumlah $94 \%$, laptop atau komputer mencapai $66 \%$ pengguna, dan tablet yang cukup dikenal dipakai oleh 23\% dibandingkan tahun 2019. ${ }^{18}$

Berdasarkan sektor usaha, perusahaan startup digital ini mengalami dampak yang berbeda-beda. Perusahaan yang mengalami kondisinya memburuk berasal dari sektor ekosistem pendukung digitalisasi, maritim dan pariwisata. Sedangkan, startup di sektor sistem pembayaran, logistik, pertanian \& kesehatan masih dalam kondisi yang baik.

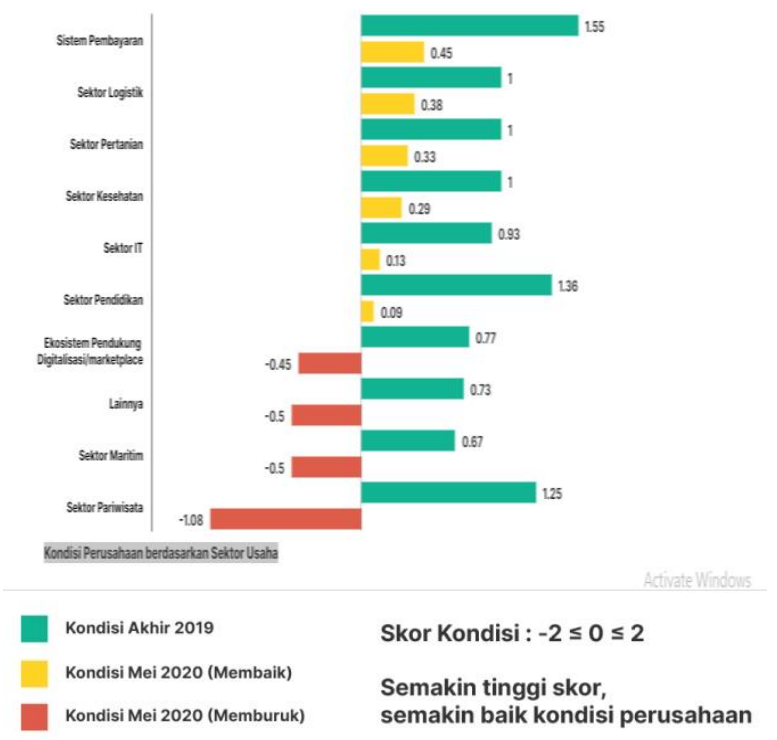

Sumber: Katadata.co.id

Secara sektoral, sektor yang benarbenar menjanjikan adalah e-commerce. Pada masa pandemi Covid-19, e-commerce menjadi yang paling tangguh dengan taksiran pertumbuhan nilai total transaksi (GMV) $54 \%$ menjadi US\$ 32 miliar pada 2020. Proyeksi pada 2025 bahkan mencapai US\$ 83 miliar. Hasil survei Bank DBS Indonesia pada 22 September 2020 semakin memperlihatkan peluang besar sektor e-commerce. Tercatat 66\% responden akan beralih berbelanja produk non-makanan dari toko fisik ke ecommerce usai pandemi Covid-19. Belum lagi didorong oleh target pemerintah untuk mendigitalisasi 3 juta UMKM pada tahun 2020 yang membuka peluang bagi ecommerce terus mencetak pelapak dan konsumen baru. ${ }^{19}$

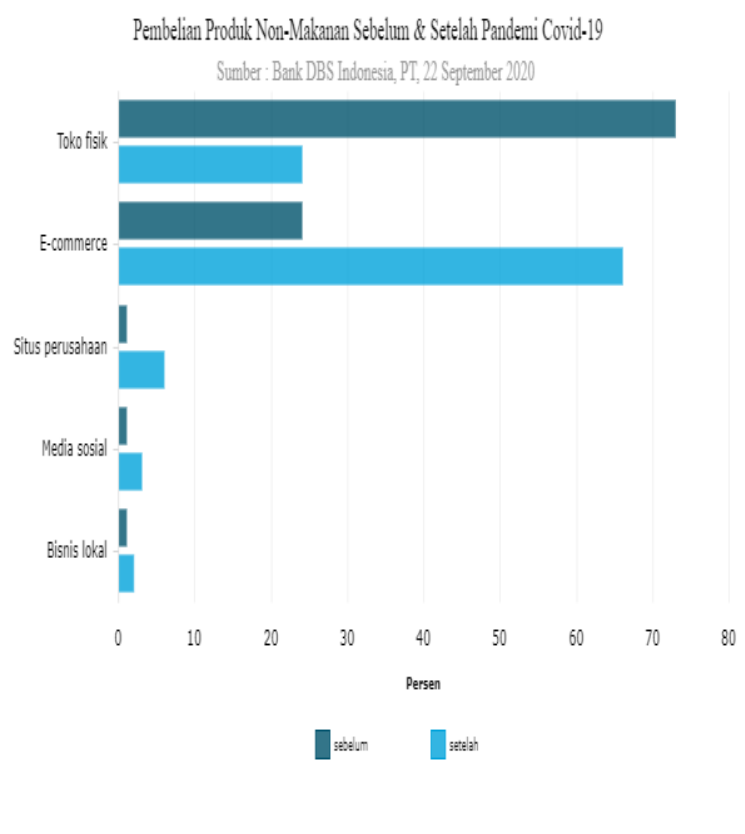

DKatadata

Sebanyak $73 \%$ responden membeli produk non-makanan, seperti pakaian, sepatu, kecantikan, furnitur, dan barang elektronik, di toko fisiknya sebelum pandemi Covid-19. Namun, setelah penyebaran virus meluas. Semakin banyak responden yang membeli produk non-makanan di e-commerce, yakni dari $24 \%$ menjadi $66 \%$. Mereka juga lebih sering berbelanja di situs perusahaan $(6 \%)$ dan

https://katadata.co.id/muhammadridhoi/analisisdat a/5fb33c772bcf1/memetakan-sektor-potensialekonomi-digital-indonesia pada 14 Desember 2021 pukul 20.00 WIB 


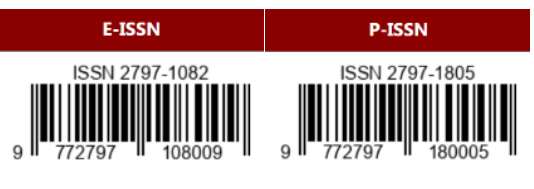

Volume 2 Nomor 1 (Desember 2021 - Februari 2022)

media sosial (3\%). Minat terhadap bisnis lokal pun meningkat. ${ }^{20}$

Ekonomi digital di Indonesia pada tahun 2020 bertumbuh $11 \%$ dibanding tahun sebelumnya meskipun ada pandemi covid-19. Angka tersebut merupakan yang tertinggi dibanding Malaysia, Filipina, Singapura, Thailand dan Vietnam. Hal tersebut didorong oleh perubahan perilaku masyarakat di masa pandemi. Masyarakat yang lebih banyak beraktivitas di rumah lebih memilih melakukan less contact economy seperti berbelanja daring, dan melakukan aktivitas pekerjaan melalui pertemuan virtual. Covid19 juga membuat konsumsi produk kesehatan dan daya tahan tubuh meningkat. Pergeseran pola konsumsi masyarakat tersebut juga mendorong UMKM yang sebelumnya menjalankan usahanya dengan cara konvensional menjadi turut beradaptasi menggunakan e-commerce. Sebanyak 1 dari 5 pelaku usaha yang aktif menjual di $e$ commerce adalah pengguna baru. ${ }^{21}$

Sebanyak $28 \%$ pedagang online di Indonesia menyatakan alasan mereka dapat bertahan selama pandemi adalah karena platform digital. $^{22}$

\section{Menurut laporan Pertemuan Tahunan} Bank Indonesia 2021, transaksi $e$ commerce_di Indonesia diproyeksi menyentuh Rp 403 triliun pada 2021. Jumlah ini tumbuh

\footnotetext{
${ }^{20}$ Andrea Lidwina, "Konsumen Beralih Beli

Produk Non-Makanan di E-Commerce saat

Pandemi Covid-19", diakses dari

https://databoks.katadata.co.id/datapublish

/2020/10/08/konsumen-beralih-beli-

produk-non-makanan-di-e-commerce-

saat-pandemi-covid-19 pada 14 Desember

2021 pukul 20.00 WIB

${ }^{21}$ Kementerian Koordinator Bidang Perekonomian Republik Indonesia, "Partisipasi Generasi Milenial dalam Era Digital untuk Menjawab Tantangan

Ekonomi Masa Depan”, diakses di laman
}

$51,6 \%$ dari tahun sebelumnya yang sebesar Rp 266 triliun. Penggunaan uang elektronik pada 2021 juga diproyeksikan tumbuh $41,2 \%$ (yoy). Cepatnya perkembangan transaksi ekonomi dan keuangan digital ini dipengaruhi oleh meningkatnya penerimaan dan preferensi masyarakat untuk berbelanja daring, meluasnya ekosistem e-commerce, serta perkembangan layanan pembayaran digital. ${ }^{23}$

Perkembangan Transaksi E-Commerce di Indonesia (2018-2022)

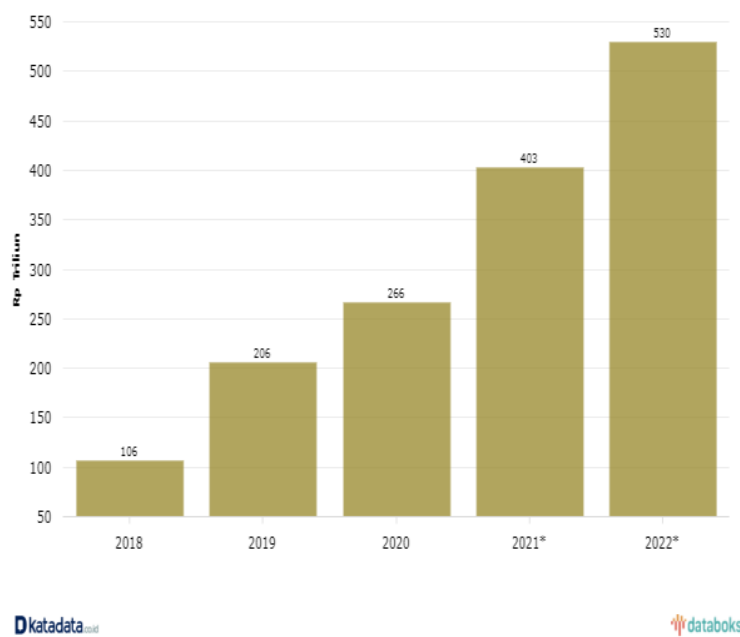

Sumber: Bank Indonesia (BI)

Berdasarkan data dari Asosiasi Ecommerce Indonesia (iDEA) per Mei 2021, jumlah pelaku UMKM yang sudah onlineboarding baru sebanyak 13,7 juta pelaku atau sekitar 21 persen dari total UMKM yang ada di Tanah Air. Menteri Perdagangan Muhammad Lutfi mengatakan, tahun 2020

https://www.ekon.go.id/publikasi/detail/3 154/partisipasi-generasi-milenial-dalamera-digital-untuk-menjawab-tantanganekonomi-masa-depan pada 5 Desember 2021 ${ }^{22}$ Dwi Hadya Jayani, Loc. Cit.

${ }^{23}$ Dwi Hadya Jayani, "Tantangan di Balik Potensi Besar Ekonomi Digital RI", diakses dari laman https://katadata.co.id/ariayudhistira/infografik/61a 5918cb7338/tantangan-di-balik-potensi-besarekonomi-digital-ri pada 14 Desember 2021 pukul 20.00 WIB 


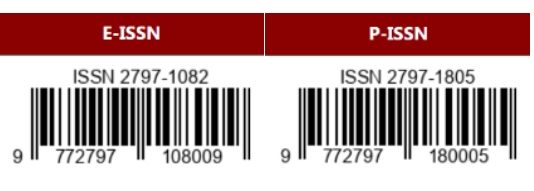

Volume 2 Nomor 1 (Desember 2021 - Februari 2022)

produk domestik bruto (PDB) Indonesia sebesar Rp 15.400 triliun. Dari jumlah tersebut, kontribusi ekonomi digital sebesar $4 \%$ dari PDB. ${ }^{24}$

Selama pandemi covid-19 ekonomi digital menjadi penopang perekonomian Indonesia. Berdasarkan data BPS, sektor informasi dan komunikasi (infokom) mencatat pertumbuhan tertinggi pada kuartal II 2020. Pertumbuhan sektor infokom 10,88\% pada kuartal II 2020 disebabkan karena selama pandemi Covid-19 masyarakat menggantungkan kehidupannya pada ekonomi digital. ${ }^{25}$

Ekonomi digital terutama peruashaan startup telah membuat berbagai aktivitas masyarakat sebagai penyedia barang/jasa ataupun sebagai penerima barang/jasa tersebut menjadi jauh lebih efisien meskipun kegiatan terbatasi selama pandemi covid-19 tanpa harus tatap muka. Ekonomi digital juga punya ruang berkembang dan menciptakan pasar yang adil. Berdasarkan hasil pembahasan dan data-data tersebut dapat disimpulkan bahwa Perusahaan startup sangat berpengaruh terhadap pertumbuhan ekonomi Indonesia selama pandemic covid-19.

\section{KESIMPULAN}

Perusahaan Startup di Indonesia ada yang menurun dan meningkat pesat selama pandemic covid-19. Perusahaan startup yang menjadi bagian ekonomi digital berkontribusi sebesar 4\% dari GDP. Perusahaan Startup dapat bertahan dan mendorong ekonomi

\footnotetext{
${ }^{24}$ Vendy Yhulia Susanto. Kontribusi ekonomi digital diramal capai $18,87 \%$ dari PDB Indonesia pada 2030 diakses dari https://nasional.kontan.co.id/news/kontribusiekonomi-digital-diramal-capai-1887-dari-pdbindonesia-pada-2030 pada 4 November 2021

${ }^{25}$ Leski Rizkinaswara, "Ekonomi Digital jadi penopang perekonomian di Tengah Pandemi”,
}

Indonesia disaat banyak sektor ekonomi lain yang gugur. Terutama perusahaan startup sector e-commerce yang meningkat pesat. Perusahaan startup sangat jelas memiliki pengaruh terhadap pertumbuhan ekonomi Indonesia pada masa pandemi covid-19. Perusahaan startup menjadi penopang perekonomian Indonesia selama pandemi karena perusahaan startup tidak terikat oleh ruang dan waktu. Perusahaan starup sebagai penyedia media sektor UMKM yang tadinya melaksanakan usahanya melalui cara konvensional menjadi turut bergantung pada perusahaan startup jenis e-commerce. Pedagang online dapat bertahan selama pandemic karena adanya platform yang dibuat oleh perusahaan startup. Nilai ekonomi digital Indonesia yang tercermin dari total nilai penjualan atau gross merchandise value (GMV) sebesar US\$ 70 miliar pada 2021. Kenaikan proyeksi tersebut didukung oleh tingkat penjualan e-commerce yang US\$ 53 miliar pada 2021 .

\section{DAFTAR PUSTAKA}

Achmad Kautsar. (2021). Saat Pertumbuhan Ekonomi Indonesia 2021 Melejit, Rakyat Masih Terjepit. Diakses dari laman https://www.pikiranrakyat.com/kolom/pr-012458575/saatpertumbuhan-ekonomi-indonesia2021-melejit-rakyat-masih-terjepit

Aulia, Sisca. "Pola Perilaku Konsumen Digital Dalam Memanfaatkan Aplikasi

\footnotetext{
diakses dari laman

https://aptika.kominfo.go.id/2020/09/ekonomidigital-jadi-penopang-perekonomian-di-tengahpandemi/ pada 14 Desember 2021 pada puku 17.30 WIB
} 


\section{Dompet \\ Digital." Jurnal}

Komunikasi 12.2 (2020): 311-324.

CNBC Indonesia. (2019). Daftar 10 Dompet

Digital Terpopuler di RI, Siapa Jawaranya?. Diakses dari CNBC Indonesia:

https://www.cnbcindonesia.com/tech/2 0190815104730-37-92151/daftar10dompet-digital-terpopuler-di-ri-siapajawaranya

CoHive. (2019). Apa Yang Dimaksud Dengan Digital Startup?, diakses dari laman https://cohive.space/blogs/apa-itudigital-startup/

Dinisari, Mia Chitra. 2020. E-Commerce dorong perekonomian Indonesia, selama pandemic COVID 19. Diakses dari

https://m.bisnis.com/amp/read/2020041 7/12/1228750/e-commerce-dorongperekonomian-indonesia-selamapandemi-covid-19-

Fadlli, Muhammad Dzul. (2021). Pertumbuhan Ekonomi 2020 Minus, lebih rendah dari perkiraan pemerintah, diakses dari laman https://studiekonomi.com/nasional/pert umbuhan-ekonomi-2020-minus-lebihrendah-dari-perkiraan-pemerintah/

Feronika, Erika . (2020). 'Pengaruh Inflasi terhadap Pertumbuhan Ekonomi Indonesia.” Vol. 13, No.3, 2020, p. 327340.

Idris, Muhammad.(2020). Pengertian ECommerce dan bedanya denga Marketplace. Diakses dari https://money.kompas.com/read/2021/0 9/11/191943626/pengertian-ecommerce-dan-bedanya-dengan$\underline{\text { marketplace?page }=\text { all }}$
Founder, Jf Gautier dan CEO.(2020) “The Impact of COVID-19 on Global Startup Ecosystems"

Hedning, Ingenida. (2020). Benarkan kebijakan social Distacing berdampak pada Ekonomi Masyarakat. Diakses dari https://www.umy.ac.id/benarkahkebijakan-social-distancingberdampak-pada-perekonomianmasyarakat

I. Husnayain and M. K. Mawardi, "Implementasi lean canvas pada startup dalam menghadapi persaingan," J. Adm. Bisnis, vol. 55, no. 2, pp. 30-38, 2018.

Indayani, Siti, and Budi Hartono. "Analisis Pengangguran Dan Pertumbuhan Ekonomi Sebagai Akibat Pandemi Covid-19." Jurnal Perspektif 18.2 (2020): 201-208.

Jaya, M. A., Ferdiana, R., \& Fauziati, S. (2017). Analisis Faktor Keberhasilan Startup Digital di Yogyakarta. Prosiding SNATIF, 167173.

Jayani, Dwi Hadya. (2021). Sektor Potensial Ekonomi Digital Indonesia. Diakses dari laman https://katadata.co.id/ariayudhistira/inf ografik/61aefade065a4/sektorpotensial-ekonomi-digital-indonesia Jayani, Dwi Hadya. (2021). Tantangan di Balik Potensi Besar Ekonomi Digital RI. Diakses dari laman https://katadata.co.id/ariayudhistira/inf ografik/61a5918cb7338/tantangan-dibalik-potensi-besar-ekonomi-digital-ri Kementerian Koordinator Bidang Perekonomian Republik Indonesia. (2021) Partisipasi Generasi Milenial dalam Era Digital untuk Menjawab Tantangan Ekonomi Masa Depan. 
Diakses di laman https://www.ekon.go.id/publikasi/detail /3154/partisipasi-generasi-milenialdalam-era-digital-untuk-menjawabtantangan-ekonomi-masa-depan

Kompas.com. (2020). Di WEF 2020, Menkominfo Pamerkan Pesatnya Perkembangan Startup Indonesia. Diakses di laman https://kominfo.go.id/content/detail/23 975/di-wef-2020-menkominfopamerkan-pesatnya-perkembanganstartup-indonesia/0/sorotan_media

Kompas.com. Pengertian E-Commerce dan bedanya dengan Marketplace. Diakses dari laman https://money.kompas.com/read/2021/0 9/11/191943626/pengertian-ecommerce-dan-bedanya-denganmarketplace?page $=$ all

Lidwina, Andrea.(2020). Konsumen Beralih Beli Produk Non-Makanan di ECommerce saat Pandemi Covid-19. Diiakses dari https://databoks.katadata.co.id/datapubl ish/2020/10/08/konsumen-beralih-beliproduk-non-makanan-di-e-commercesaat-pandemi-covid-19

Miftahudin, Husen. (2021). Dorong Pemulihan Ekonomi, Menparekraf Genjot Peran Startup Digital RI. Diakses dari laman https://www.medcom.id/ekonomi/bisni s/4KZzWqJK-dorong-pemulihanekonomi-menparekraf-genjot-peranstartup-digital-ri

Mulachela, husen. (2021). Pengertian Startup, Istilah dan bedanya dengan Bisnis Konvensional. Diakses dari laman https://katadata.co.id/safrezifitra/digital /6110a5251ff83/pengertian-startup- istilah-dan-bedanya-dengan-bisniskonvensional

Mutaqih, Galih. Taqi, Muhammad, dan Arifin, Bastanul. (2020)."Job Performance During COVID-19 Pandemic: A Study on Indonesian Startup Companies" ISSN: 2288-4637. Vol 7 No.12.

Ridhoi, Muhammad Ahsan. (2020). Memetakan Sektor Potensial Ekonomi Digital Indonesia - Analisis Data Katadata", diakses dari laman https://katadata.co.id/muhammadridhoi lanalisisdata/5fb33c772bcf1/memetaka n-sektor-potensial-ekonomi-digitalindonesia

Leski Rizkinaswara. (2020). Ekonomi Digital jadi penopang perekonomian di Tengah Pandem. Diakses dari laman https://aptika.kominfo.go.id/2020/09/ek onomi-digital-jadi-penopang-

perekonomian-di-tengah-pandemi/

Rosmayanti. (2019). Apa Itu Dompet Digital?. Diakses dari laman https://www.wartaekonomi.co.id/read2 12834/apa-itu-dompet-digital.html

Vendy Yhulia Susanto. (2021). Kontribusi ekonomi digital diramal capai 18,87\% dari PDB Indonesia pada 2030. Diakses dari laman https://nasional.kontan.co.id/news/kont ribusi-ekonomi-digital-diramal-capai1887-dari-pdb-indonesia-pada-2030

Yamali, Fakhrul Rozi, dan Ririn Noviyanti Putri. "Dampak Covid-19 Terhadap Ekonomi Indonesia." Ekonomis: Journal of Economics and Business 4.2 (2020): 384-388. 